\title{
Cancer Chemotherapy Specific to Acidic Nests
}

\author{
Hiroshi Kobayashi \\ Graduate School of Pharmaceutical Sciences, Chiba University, Chiba 260-8675, Japan; \\ hiroshi@faculty.chiba-u.jp; Tel.: +81-263872529 \\ Academic Editor: Samuel Mok \\ Received: 19 March 2017; Accepted: 18 April 2017; Published: 20 April 2017
}

\begin{abstract}
The realization of cancer therapeutics specific to cancer cells with less of an effect on normal tissues is our goal. Many trials have been carried out for this purpose, but this goal is still far from being realized. It was found more than 80 years ago that solid cancer nests are acidified, but in vitro studies under acidic conditions have not been extensively studied. Recently, in vitro experiments under acidic conditions were started and anti-cancer drugs specific to acidic areas have been identified. Many genes have been reported to be expressed at a high level under acidic conditions, and such genes may be potent targets for anti-cancer drugs specific to acidic nests. In this review article, recent in vitro, in vivo, and clinical achievements in anti-cancer drugs with marked efficacy under acidic conditions are summarized, and the clinical use of anti-cancer drugs specific to acidic nests is discussed.
\end{abstract}

Keywords: chemotherapy; acidosis of cancer nests; statins; cantharidin; manumycin A; ionomycin; acidosis-dependent gene expression

\section{Introduction}

Over the past 80 years, many researchers have tried to measure the $\mathrm{pH}$ of tumor tissues [1], and it is now accepted that solid cancer nests are generally acidified [2,3]. The acidosis is mediated via the acceleration of glycolysis, which is called the Warburg effect [4]. This acceleration is mainly induced by the limited supply of oxygen [2]. In another report, an increase in glycolytic activity was observed with a sufficient supply of oxygen in solid cancer nests [4].

Drugs with increased efficacy to inhibit cancer cell proliferation under acidic conditions have been identified recently. Such drugs may have less effects on normal tissues, whose $\mathrm{pH}$ is slightly alkaline. However, their clinical application is still limited. In this review, recent achievements in anti-cancer drugs with marked efficacy under acidic conditions are summarized, and the clinical use of such acidosis-dependent drugs is discussed.

\section{Metabolic Pathways Working under Acidic Conditions}

The effect of acidosis on cancer cell functions has not been well discussed until recently. One reason may be that the $\mathrm{pH}$ change in cancer nests is often less than $1 \mathrm{pH}$ unit. Another may be the argument that the $\mathrm{pH}$ in intracellular spaces is not affected by the acidification of the surroundings within this narrow range of $\mathrm{pH}$ change. Cytosolic acidification, however, was observed in cancer cells with a decrease in the $\mathrm{pH}$ of the culture medium [5,6]. Cytosolic $\mathrm{pH}$ values were 7.4 and 6.9 in media with a pH of 7.4 and 6.5, respectively [5]. In another report, cytosolic pH values were 7.4 and 6.8 in media with a $\mathrm{pH}$ of 7.4 and 6.2, respectively [6]. These data suggest that the $\mathrm{pH}$ homeostatic capacity of the cytosolic space is not strong enough to maintain a constant cytosolic $\mathrm{pH}$. Thus, the cytosol may be acidified in acidic cancer nests.

A question that arises is whether cytosolic acidification affects cellular metabolism within the narrow $\mathrm{pH}$ change. Since all enzymes mediating cellular metabolism have $\mathrm{pH}$-dependent activity, 
cytosolic acidification affects the activities of some metabolic pathways. The change of $1 \mathrm{pH}$ unit corresponds to a 10-fold change in the proton concentration, which should affect enzyme activities. When a metabolic pathway declines at acidic $\mathrm{pH}$, it would be beneficial for an alternative pathway to work to compensate the decline. It is well known that bacteria have metabolic pathways that function under acidic conditions [7]. These previous insights led us to consider that mammals also have alternative systems working in acidic diseased areas, such as cancer nests, inflammation loci, and areas of infarction.

Our research group investigated the expression of 24,000 genes in cancer cells cultured in media at $\mathrm{pH} 7.5$ and 6.7, and found that the mRNA levels of approximately 700 genes were increased at the acidic $\mathrm{pH}$ [8]. Among the 700 genes, $24 \%$ encoded signal proteins, external ligands, and regulatory proteins. Many of these proteins may participate in the promotion and regulation of cell proliferation. These results suggest that a large number of proteins are working preferentially under acidic conditions.

Lao et al. $[9,10]$ identified a protein whose expression level at $\mathrm{pH} 6.3$ was the same as that at $\mathrm{pH} 7.4$ in Chinese hamster ovary cells, but this protein was only essential for growth under acidic conditions. The same protein was found in mammalian cells [11]. These results suggest that mammalian cells have proteins required for growth at an acidic $\mathrm{pH}$, although their synthesis is constitutive, besides proteins encoded by genes whose expression increases at an acidic $\mathrm{pH}$.

Recently, an increased expression of OCT-4 was observed in fibroblasts growing in an acidic medium at $\mathrm{pH} 6.5$ for 7 days [12]. Hjelmeland et al. [13] reported increased expressions of OCT-4, Olig2, and Nanog in glioma stem cells treated at $\mathrm{pH} 6.5$ for 6 days. The measurement of gene expression under acidic conditions is still limited. Without having to wait for future studies, the present data suggest that mammalian cells contain a high number of acidosis-dependent genes.

\section{Acidosis-Dependent Anti-Cancer Drugs}

The investigation of cancer-specific targets has been focused on, which may be useful for anti-cancer chemotherapy with less effects on normal tissues. Cancer-specific targets vary in different organs and, more seriously from a treatment perspective, they vary among individuals. The investigation of cancer-specific targets is still in progress. The acidification of solid cancer nests provides a clue that molecules involved in metabolic pathways working preferentially at an acidic $\mathrm{pH}$ may be potent targets for chemotherapy against cancers, because such molecules would be less functional in normal tissues, whose $\mathrm{pH}$ is slightly alkaline.

Fukamachi et al. [14] screened approximately 280 compounds including enzyme inhibitors using HeLa cells in media at $\mathrm{pH}$ 7.7-7.4 and 6.7-6.6, and two compounds, lovastatin and cantharidin, were found to inhibit cell growth preferentially at an acidic $\mathrm{pH}$. In contrast, the inhibitory efficacies of vinblastine sulfate, paclitaxel, aclarubicin, aphidicolin, trichostatin A, and 17-AAG decreased at an acidic $\mathrm{pH}$ (Table 1). The efficacies of 14 compounds were almost the same at both $\mathrm{pH}$ values (Table 1). Others showed no inhibition of HeLa cell proliferation at $1 \mu \mathrm{M}$ in alkaline or acidic media. Manumycin A and ionomycin preferentially showed an inhibitory effect at an acidic $\mathrm{pH}$ in mesothelioma [14] and synovial cells [15], respectively.

Table 1. Inhibitory efficacy of various compounds on cell proliferation under acidic conditions.

\begin{tabular}{cl}
\hline Efficacy & \multicolumn{1}{c}{ Compounds } \\
\hline Higher at acidic $\mathrm{pH}$ & lovastatin, cantharidin manumycin $\mathrm{A} *$, ionomycin ${ }^{* *}$ \\
\hline Lower at acidic $\mathrm{pH}$ & aphidicolin, vinblastine sulfate, paclitaxel, aclarubicin, trichostatin A, 17-AAG \\
\hline No change at acidic $\mathrm{pH}$ & $\begin{array}{l}\text { mitomycin } \mathrm{C}, \text { bleomycin sulfate, methotrexate, daunorubicin, actinomycin D, } \\
\text { camptothecin, etoposide, cytochalasin } \mathrm{D}, \text { kenpaullone, cycloheximide, radicicol, } \\
\text { cucurbitacin 1, hydroxyurea, doxorubicin }\end{array}$ \\
\hline
\end{tabular}

Inhibitory effect on HeLa cell proliferation was measured in media with an initial $\mathrm{pH}$ of 7.7 and 6.7 that decreased to 7.4 and 6.6, respectively, after 5 days of culture [14]. * mesothelioma cells [14], ${ }^{* *}$ synovial cells [15]. 
The question is whether extracellular $\mathrm{pH}$, cytosolic $\mathrm{pH}$, or both are responsible for high efficacy of acidosis-dependent drugs. The target molecules of statins, cantharidin, and manumycin A have been reported to be cytosolic enzymes, as described below, and the accumulation of statins was almost the same at both $\mathrm{pH} 6.7$ and 7.4 [16]. These results suggest that cytosolic acidification is the main factor to improve the efficacy of these drugs.

\subsection{Statins}

Lovastatin, simvastatin, and atorvastatin were shown to inhibit cell proliferation of all cancer cells tested preferentially in medium at pH $6.7[14,15]$. Statins inhibit mevalonate pathways and attenuate the level of farnesyl diphosphate, which is used for two metabolic pathways; syntheses of cholesterol and geranylgeranyl diphosphate [15]. Geranylgeranyl diphosphate and farnesyl diphosphate are used for protein prenylation [15]. Prenylated small G proteins, such as Ras, Rho, Rab, Arf, and Ran [17], move to membranes and work as proteins for signal pathways [18]. Therefore, statins decrease the levels of cholesterol and prenylated proteins. The effect of statins on the blood level of cholesterol has been researched, and these drugs have been developed as agents against hyperlipidemia. The decrease in protein prenylation was shown to be the main mechanism for the inhibition of cancer cell proliferation at an acidic $\mathrm{pH}$ in vitro [14].

\subsection{Cantharidin}

Cantharidin is an active compound of the traditional Chinese medicine mylabris, prepared from the Chinese blister beetle, and mylabris has been used to cure cancer for more than 700 years in China [19]. Its clinical application is still limited, although the effectiveness of cantharidin has been reported [20]. The main problem is toxicity, especially that causing liver injuries [21]. Cantharidin inhibited the proliferation of mesothelioma at $1 \mu \mathrm{M}$ in an acidic medium [14], and ED50 in Ehrlich ascites carcinoma was approximately $130 \mu \mathrm{M}$ in an alkaline medium used conventionally [22]. In a mouse model, the i.v. administration of $1 \mathrm{mg} / \mathrm{kg}$ every 3 days was shown to be effective [23]. When sodium cantharidin was administered ( $0.5 \mathrm{~g} /$ day) to patients with gastric cancer who received mainly fluoropyrimidine-based chemotherapy, no significant toxicity was observed [24]. Similar results were reported in patients with breast cancer receiving combined chemotherapy with cyclophosphamide, epirubicin, and docetaxel [25]. These results suggest that cantharidin can be used alone as an anti-cancer medicine. Vitamin $\mathrm{C}$ administration was reported to attenuate the liver injuries induced by cantharidin in mice [21], but the effect of vitamin C on anti-cancer therapy with cantharidin remains unclear. Derivatives of this drug have been synthesized to reduce the toxicity [26]. The target of cantharidin was reported to be protein phosphatases, PP1 and PPA2 [27], but the mechanism leading to the inhibition of cell proliferation at an acidic $\mathrm{pH}$ is unknown.

\subsection{Manumycin A}

Manumycin A was isolated from Streptomyces [28], and inhibits the prenylation of small G-protein [29]. The administration of manumycin A prevented the growth of triple-negative breast cancers, in which the expressions of estrogen, progesterone, and HER2 receptors were negative, in nude mice [29]. Manumycin A was also shown to increase the efficacy of other anti-cancer drugs in animal models [28]. To the best of the author's knowledge, no clinical trial using manumycin A has been reported. The main reason for the lack of clinical application would be that the in vitro efficacy to inhibit cancer cell growth is weak under alkaline conditions [14,28].

\subsection{Ionomycin}

Ionomycin was reported to inhibit cell proliferation much more markedly at an acidic $\mathrm{pH}$ [15]. Ionomycin increases membrane permeability to calcium ions and induces cell death [30]. It is unclear why the effect of ionomycin on cell death increases at an acidic $\mathrm{pH}$. The intracellular calcium ion concentration was higher in an acidic medium than that in an alkaline medium [31]. The increased 
cytotoxicity of ionomycin at an acidic $\mathrm{pH}$ might be related to the increase in the intracellular calcium ion concentration at an acidic $\mathrm{pH}$.

\subsection{Doxorubicin}

Doxorubicin did not show a clear difference in the inhibition of HeLa cell growth between alkaline and acidic $\mathrm{pH}$ values, but the cell shape changed at an acidic $\mathrm{pH}$ at $1 \mu \mathrm{M}$ [14], suggesting that cell growth could be inhibited at a higher concentration under acidic conditions, but no data confirming this have been reported.

\section{Anti-Cancer Drugs Whose Efficacy Decreases at an Acidic pH}

Anti-cancer drugs with marked efficacy at an acidic $\mathrm{pH}$ are still limited. In the case of many anti-cancer drugs, cancer cells become tolerant to chemotherapy. Multi-drug resistance was induced by acidosis in rat prostate cancer cells via increasing the activity of p-glycoprotein [32]. Uptakes of mitoxantrone and topotecan decreased in vitro at an acidic $\mathrm{pH}$ [5]. Reduced drug accumulation may be a reason for the decrease in chemotherapeutic efficacy at an acidic $\mathrm{pH}$. Cancer progression occurs frequently with inadequate angiogenesis, resulting in the limited supply of drugs from blood vessels [2]. This is a reason for the decrease in the efficacy of anti-cancer drugs in vivo. The mRNA levels of approximately 850 genes were decreased at an acidic $\mathrm{pH}$ among 24,000 genes tested in mesothelioma [8]. The functional decline of the target molecules may cause resistance to anti-cancer drugs in an acidic environment.

\section{Proposal for Clinical Usage of Statins}

As described above, the clinical protocol for the use of statins against cancers has not been established. Kawata et al. [33] reported that pravastatin promoted prolonged survival in patients with advanced hepatocellular carcinoma. Since this report, promising results have been reported with statin use in patients bearing a wide array of cancer types, while some large meta-analyses have not found an association between statin use and outcomes in cancer patients (for reviews, see [34,35]). Statins have been prescribed as anti-hyperlipidemia agents. Defined daily doses (DDDs) of statins recommended by the WHO Collaborating Centre for Drug Statistics Methodology (WHOCC) are 20 to $60 \mathrm{mg}$ (Table 2). These values were determined based on the effective concentration for decreasing the blood cholesterol level. The main mechanism for the anti-cancer effect of statins is the attenuation of protein prenylation, not the inhibition of cholesterol synthesis [14]. Therefore, the recommended DDDs may not be sufficient for therapy against cancers. In fact, the data obtained in mouse models demonstrated that the effective concentration of statins to attenuate cancer progression was $10-50 \mathrm{mg} / \mathrm{kg} /$ day administered orally (Table 2) [36-43]. The estimated dose of simvastatin for oral administration in a human patient whose weight is $60 \mathrm{~kg}$ is $3000 \mathrm{mg} /$ day, which is 100-fold higher than the DDD range. In the case of lovastatin, $600-960 \mathrm{mg} /$ day of lovastatin are estimated for a human patient whose weight is $60 \mathrm{~kg}$, while the DDD is $45 \mathrm{mg}$. Forty $\mathrm{mg} / \mathrm{kg} /$ day of fluvastatin in mice corresponds to $2400 \mathrm{mg} /$ day for oral administration in a human patient whose weight is $60 \mathrm{~kg}$, which is 40 -fold higher than the DDD. The administration of statins at a low dose may have the opposite effects in clinical investigations. 
Table 2. Effective doses of statins in mouse models.

\begin{tabular}{|c|c|c|c|}
\hline \multirow{2}{*}{ Statins } & \multirow{2}{*}{ Defined Daily Doses } & \multicolumn{2}{|c|}{ Mouse Model } \\
\hline & & Effective Dose & Cancers (in literature) \\
\hline \multirow{2}{*}{ Simvastatin } & \multirow{2}{*}{$30 \mathrm{mg}$} & $50 \mathrm{mg} / \mathrm{kg} /$ day * & melanoma [36] \\
\hline & & $50 \mathrm{mg} / \mathrm{kg} /$ day * & colon cancer [37] \\
\hline \multirow{2}{*}{ Lovastatin } & \multirow{2}{*}{$45 \mathrm{mg}$} & $10 \mathrm{mg} / \mathrm{kg} /$ day * & thyroid cancer [38] \\
\hline & & $16 \mathrm{mg} / \mathrm{kg} /$ day * & ascites tumor [39] \\
\hline \multirow{2}{*}{ Fluvastatin } & \multirow{2}{*}{$60 \mathrm{mg}$} & $40 \mathrm{mg} / \mathrm{kg} /$ day * & leukemia [40] \\
\hline & & $15 \mathrm{mg} / \mathrm{kg} /$ day ** & breast cancer [41] \\
\hline \multirow{2}{*}{ Atorvastatin } & \multirow{2}{*}{$20 \mathrm{mg}$} & $16 \mathrm{mg} / \mathrm{kg} /$ day ${ }^{* *}$ & ascites tumor [42] \\
\hline & & $10 \mathrm{mg} / \mathrm{kg} /$ day $* *$ & prostate cancer [43] \\
\hline
\end{tabular}

* oral, ${ }^{* *}$ intraperitoneal.

Since statins are effective under acidic conditions, their efficacy may be dependent on the acidosis of cancer nests. Acidosis-dependent anti-cancer drugs are less effective in areas insufficiently acidified, such as at an early stage, in blood, or in cancer nests where angiogenesis is highly active. In fact, the negative effect of statins has been reported in patients with early-stage hepatocellular carcinoma [44], follicular lymphoma [45], and prostate cancer after radical prostatectomy [46]. This is another reason for the opposite results in clinical examinations. On the basis of these investigations, the author would like to propose a clinical protocol whereby statins are first used, and then other methods, such as excision, radiation, immunotherapy, and chemotherapy with conventional drugs whose efficacy is not dependent on the $\mathrm{pH}$, are applied after cancer nests have been reduced in size (Figure 1). The strategy to use conventional drugs in this stage would be advantageous, because the drug dosage can be reduced in small cancer nests to ameliorate the side effects in normal tissues.
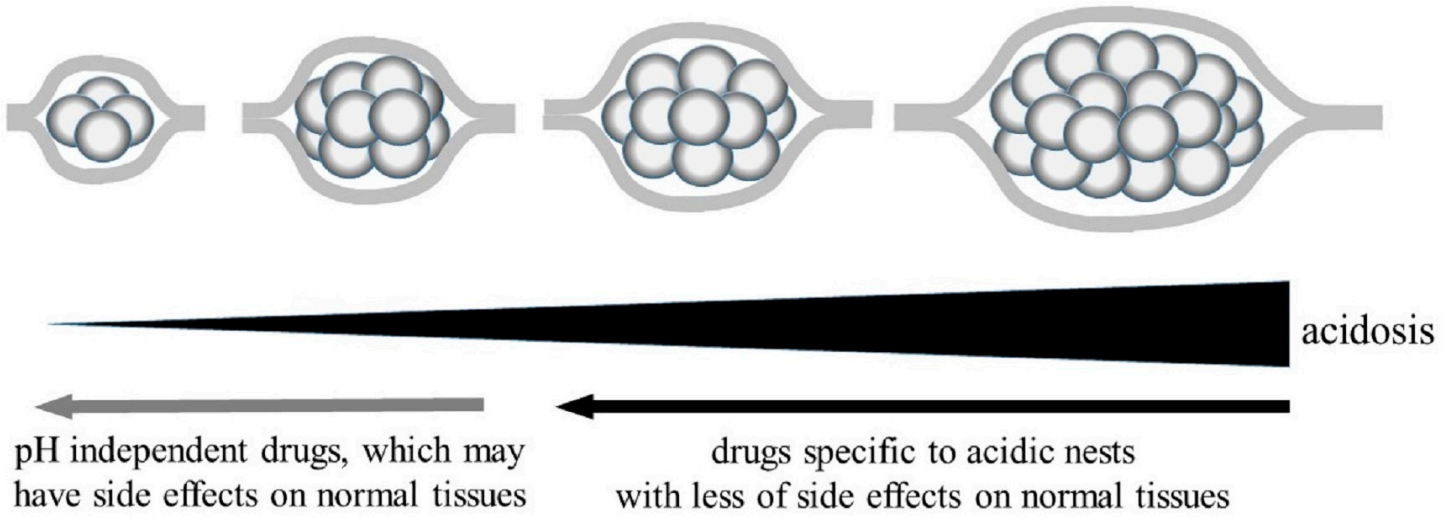

Figure 1. Proposal for chemotherapy using anti-cancer drugs specific to acidic nests.

Chemotherapy specific to acidic cancer nests has been argued to have weaker effects on cells in normal tissues, whose $\mathrm{pH}$ is slightly alkaline. A serious side effect of conventional drugs is the dysfunction of the immune system. Statins inhibited the proliferation of immune cells at an acidic $\mathrm{pH}$, but the cytotoxicity of statins against immune cells was very low at $\mathrm{pH} 7.5$ [47]. This report suggests that statins have less of an effect on the immune system at a level sufficient for the attenuation of cancer progression in acidic areas. Statins are now prescribed as drugs against hyperlipidemia, and no dysfunction of the immune system caused by statins has been reported. Statins were reported to increase incident diabetes, but the adjusted hazard ratio was 1.04 to 1.17 [48]. The risk of a major cardiovascular event was less than $1 \%$ in patients treated with statins [49]. Statin administration at a high dose may cause hypocholesterolemia. Although no clinical protocol for treatment against hypocholesterolemia induced by drugs has been reported, it might be cured by a special diet, 
as reported in hypobetalipoproteinemia and abetalipoproteinemia caused by genetic mutation [50]. These observations indicate that the side effects of statins on normal tissues are not serious.

\section{Measurements of Acidity in Cancer Nests}

The in vivo measurement of acidity in cancer nests would help us use acidosis-dependent anti-cancer drugs more efficiently. Recently, new in vivo methods to measure the $\mathrm{pH}$ of cancer areas have been developed in animal models [51,52]. As described above, many genes are expressed at high levels under acidic conditions, and the measurement of the degraded materials of mRNAs encoded by such genes in blood might be useful to understand the acidity of cancer nests. The genes, whose expression increased with the acidification of cancer nests, have been shown to be different in different organs [53]. The measurement of the acidity is important not only for evaluation of the cancer progression, but also to decide on whether acidosis-dependent anti-cancer drugs are applicable.

\section{Exploitation of Other Drugs Specific to Acidic Cancer Nests}

Four compounds have been demonstrated to show anti-cancer activity preferentially under acidic conditions. A question is whether other acidosis-dependent anti-cancer drugs can be exploited in the future. Many genes were shown to be expressed at high levels at an acidic $\mathrm{pH}$ [8]. Among the genes whose expression increased at an acidic $\mathrm{pH}, 24 \%$ can be argued to encode factors for supporting cell proliferation under acidic conditions [8]. Medium acidosis increased the phosphorylation of AKT and ERK, and induced nuclear translocation of NF-KB [54]. These observations suggest the possibility of new compounds being developed in the future.

A vast array of traditional medicines have been prepared from natural sources. If acidosis-dependent anti-cancer compounds are included in some traditional medicines used for cancer therapy for a long time, such compounds would be identified in in vitro assay using an acidic medium.

For the effective use of anti-cancer drugs in acidic cancer nests, it would be a good idea to develop nanoparticles in which a drug can be embedded at an alkaline $\mathrm{pH}$ and subsequently released under acidic conditions.

\section{Conclusions}

Anti-cancer drugs specific to acidic conditions have been detected in in vitro studies using an acidic medium. Chemotherapy using such drugs would ameliorate the serious conditions that develop with the current anti-cancer chemotherapy, because they would exhibit less of an effect on normal tissues, whose $\mathrm{pH}$ is slightly alkaline. Few drugs have been shown to exhibit high-level efficacy for attenuating cancer cell growth under acidic conditions until now. It is highly likely that new acidosis-dependent anti-cancer drugs will be developed, and cancer chemotherapy specific to acidic environments may be exploited as a standard protocol in the future. Some researchers are now focusing on studies of the efficacy of anti-cancer drugs under acidic conditions. The author hopes that many researchers will become interested in the "acidic world," and that cancer chemotherapy will enter new areas.

Conflicts of Interest: The author declares no conflict of interest.

\section{References}

1. Meyer, K.A.; Kammerling, E.M.; Amtman, L.; Koller, M.; Hoffman, S.J. pH studies of malignant tissues in human beings. Cancer Res. 1948, 8, 513-518. [PubMed]

2. Vaupel, P.; Kallinowski, F.; Okunieff, P. Blood flow, oxygen and nutrient supply, and metabolic microenvironment of human tumors. Cancer Res. 1989, 49, 6449-6465. [PubMed]

3. Helmlinger, G.; Yuan, F.; Dellian, M.; Jain, R.K. Interstitial $\mathrm{pH}$ and $\mathrm{pO}_{2}$ gradients in solid tumors in vivo: High-resolution measurements reveal a lack of correlation. Nat. Med. 1997, 3, 177-182. [CrossRef] [PubMed] 
4. Warburg, O. On the origin of cancer cells. Science 1956, 123, 309-314. [CrossRef] [PubMed]

5. Vukovic, V.; Tannock, I.F. Influence of low $\mathrm{pH}$ on cytotoxicity of paclitaxel, mitoxantrone and topotecan. Br. J. Cancer 1997, 75, 1167-1172. [CrossRef] [PubMed]

6. Fukamachi, T.; Saito, H.; Kakegawa, T.; Kobayashi, H. Different proteins are phosphorylated under acidic environments in Jurkat cells. Immunol. Lett. 2002, 82, 155-158. [CrossRef]

7. Sun, Y.; Fukamachi, T.; Saito, H.; Kobayashi, H. Adenosine deamination increases the survival under acidic conditions in Escherichia coli. J. Appl. Microbiol. 2012, 112, 775-781. [CrossRef] [PubMed]

8. Fukamachi, T.; Ikeda, S.; Wang, X.; Saito, H.; Tagawa, M.; Kobayashi, H. Gene expressions for signal transduction under acidic conditions. Genes 2013, 4, 65-85. [CrossRef] [PubMed]

9. Lao, Q.; Fukamachi, T.; Saito, H.; Kuge, O.; Nishijima, M.; Kobayashi, H. Requirement of an IkappaB-beta $\mathrm{COOH}$ terminal region protein for acidic-adaptation in $\mathrm{CHO}$ cells. J. Cell. Physiol. 2006, 207, 238-243. [CrossRef] [PubMed]

10. Lao, Q.; Kuge, O.; Fukamachi, T.; Kakegawa, T.; Saito, H.; Nishijima, M.; Kobayashi, H. An IkappaB-beta $\mathrm{COOH}$ terminal region protein is essential for the proliferation of $\mathrm{CHO}$ cells under acidic stress. J. Cell. Physiol. 2005, 203, 186-192. [CrossRef] [PubMed]

11. Fukamachi, T.; Lao, Q.; Okamura, S.; Saito, H.; Kobayashi, H. CTIB (C-terminus protein of IkB- $\beta$ ): A novel factor required for acidic adaptation. Adv. Exp. Med. Biol. 2006, 584, 219-228. [PubMed]

12. Som, A.; Bloch, S.; Ippolito, J.E.; Achilefu, S. Acidic extracellular $\mathrm{pH}$ of tumors induces octamer-binding transcription factor 4 expression in murine fibroblasts in vitro and in vivo. Sci. Rep. 2016, 6, 27803. [CrossRef] [PubMed]

13. Hjelmeland, A.B.; Wu, Q.; Heddleston, J.M.; Choudhary, G.S.; MacSwords, J.; Lathia, J.D.; McLendon, R.; Lindner, D.; Sloan, A.; Rich, J.N. Acidic stress promotes a glioma stem cell phenotype. Cell Death Differ. 2011, 18, 829-840. [CrossRef] [PubMed]

14. Fukamachi, T.; Chiba, Y.; Wang, X.; Saito, H.; Tagawa, M.; Kobayashi, H. Tumor specific low pH environments enhance the cytotoxicity of lovastatin and cantharidin. Cancer Lett. 2010, 297, 182-189. [CrossRef] [PubMed]

15. Fukamachi, T.; Wang, X.; Mochizuki, Y.; Maruyama, C.; Saito, H.; Kobayashi, H. Acidic environments enhance the inhibitory effect of statins on proliferation of synovial cells. Int. Immunopharmacol. 2013, 17, 148-153. [CrossRef] [PubMed]

16. Fukamachi, T.; Kobayashi, H.; Graduate School of Pharmaceutical Sciences, Chiba University, Chiba, Japan. Unpublished work. 2010.

17. Takai, Y.; Sasaki, T.; Matozaki, T. Small GTP-binding proteins. Physiol. Rev. 2001, 81, 153-208. [PubMed]

18. Palsuledesai, C.C.; Distefano, M.D. Protein prenylation: Enzymes, therapeutics, and biotechnology applications. ACS Chem. Biol. 2015, 10, 51-62. [CrossRef] [PubMed]

19. Wang, G.S. Medical uses of mylabris in ancient China and recent studies. J. Ethnopharmacol. 1989, 26, 147-162. [CrossRef]

20. Shao, H.; Hong, G.; Luo, X. Evaluation of sodium cantharidinate/vitamin B6 in the treatment of primary liver cancer. J. Cancer Res. Ther. 2014, 10 (Suppl. 1), 75-78. [PubMed]

21. Wu, W.; Su, M.; Li, T.; Wu, K.; Wu, X.; Tang, Z. Cantharidin-induced liver injuries in mice and the protective effect of vitamin C supplementation. Int. Immunopharmacol. 2015, 28, 182-187. [CrossRef] [PubMed]

22. Verma, A.K.; Prasad, S.B. Bioactive component, cantharidin from Mylabris cichorii and its antitumor activity against Ehrlich ascites carcinoma. Cell. Biol. Toxicol. 2012, 28, 133-147. [CrossRef] [PubMed]

23. Li, C.C.; Yu, F.S.; Fan, M.J.; Chen, Y.Y.; Lien, J.C.; Chou, Y.C.; Lu, H.F.; Tang, N.Y.; Peng, S.F.; Huang, W.W.; et al. Anticancer effects of cantharidin in A431 human skin cancer (Epidermoid carcinoma) cells in vitro and in vivo. Environ. Toxicol. 2017, 32, 723-738. [CrossRef] [PubMed]

24. Zhan, Y.P.; Huang, X.E.; Cao, J.; Lu, Y.Y.; Wu, X.Y.; Liu, J.; Xu, X.; Xu, L.; Xiang, J.; Ye, L.H. Clinical study on safety and efficacy of Qinin ${ }^{\circledR}$ (cantharidin sodium) injection combined with chemotherapy in treating patients with gastric cancer. Asian Pac. J. Cancer Prev. 2012, 13, 4773-4776. [CrossRef] [PubMed]

25. Wang, L.; Huang, X.E.; Cao, J. Clinical study on safety of cantharidin sodium and shenmai injection combined with chemotherapy in treating patients with breast cancer postoperatively. Asian Pac. J. Cancer Prev. 2014, 15, 5597-5600. [CrossRef] [PubMed]

26. Dorn, D.C.; Kou, C.A.; Png, K.J.; Moore, M.A. The effect of cantharidins on leukemic stem cells. Int. J. Cancer 2009, 124, 2186-2199. [CrossRef] [PubMed] 
27. Honkanen, R.E. Cantharidin, another natural toxin that inhibits the activity of serine/threonine protein phosphatases types 1 and 2A. FEBS Lett. 1993, 330, 283-286. [CrossRef]

28. Solár, P.; Sačková, V.; Hrčková, G.; Demečková, V.; Kassayová, M.; Bojková, B.; Mudroňová, D.; Gancarčíková, S.; Jendželovský, R.; Fedoročko, P. Antitumor effect of the combination of manumycin A and Immodin is associated with antiplatelet activity and increased granulocyte tumor infiltration in a 4T1 breast tumor model. Oncol. Rep. 2017, 37, 368-378. [PubMed]

29. Singha, P.K.; Pandeswara, S.; Venkatachalam, M.A.; Saikumar, P. Manumycin A inhibits triple-negative breast cancer growth through LC3-mediated cytoplasmic vacuolation death. Cell Death Dis. 2013, 4, e457. [CrossRef] [PubMed]

30. Yin, M.Z.; Park, S.W.; Kang, T.W.; Kim, K.S.; Yoo, H.Y.; Lee, J.; Kim, S.J. Activation of K ${ }^{+}$channel by 1-EBIO rescues the head and neck squamous cell carcinoma cells from $\mathrm{Ca}^{2+}$ ionophore-induced cell death. Korean J. Physiol. Pharmacol. 2016, 20, 25-33. [CrossRef] [PubMed]

31. Ahmed, K.H.; Pelster, B. Interdependence of $\mathrm{Ca}^{2+}$ and proton movements in trout hepatocytes. J. Exp. Biol. 2007, 210, 3473-3483. [CrossRef] [PubMed]

32. Sauvant, C.; Nowak, M.; Wirth, C.; Schneider, B.; Riemann, A.; Gekle, M.; Thews, O. Acidosis induces multi-drug resistance in rat prostate cancer cells (AT1) in vitro and in vivo by increasing the activity of the p-glycoprotein via activation of p38. Int. J. Cancer 2008, 123, 2532-2542. [CrossRef] [PubMed]

33. Kawata, S.; Yamasaki, E.; Nagase, T.; Inui, Y.; Ito, N.; Matsuda, Y.; Inada, M.; Tamura, S.; Noda, S.; Imai, Y.; et al. Effect of pravastatin on survival in patients with advanced hepatocellular carcinoma. A randomized controlled trial. Br. J. Cancer 2001, 84, 886-891. [CrossRef] [PubMed]

34. Wang, A.; Wakelee, H.A.; Aragaki, A.K.; Tang, J.Y.; Kurian, A.W.; Manson, J.E.; Stefanick, M.L. Protective effects of statins in cancer: Should they be prescribed for high-risk patients? Curr. Atheroscler. Rep. 2016, 18, 72. [CrossRef] [PubMed]

35. Chae, Y.K.; Yousaf, M.; Malecek, M.K.; Carneiro, B.; Chandra, S.; Kaplan, J.; Kalyan, A.; Sassano, A.; Platanias, L.C.; Giles, F. Statins as anti-cancer therapy; Can we translate preclinical and epidemiologic data into clinical benefit? Discov. Med. 2015, 20, 413-427. [PubMed]

36. Kretzer, I.F.; Maria, D.A.; Guido, M.C.; Contente, T.C.; Maranhão, R.C. Simvastatin increases the antineoplastic actions of paclitaxel carried in lipid nanoemulsions in melanoma-bearing mice. Int. J. Nanomed. 2016, 11, 885-904.

37. Cho, S.J.; Kim, J.S.; Kim, J.M.; Lee, J.Y.; Jung, H.C.; Song, I.S. Simvastatin induces apoptosis in human colon cancer cells and in tumor xenografts, and attenuates colitis-associated colon cancer in mice. Int. J. Cancer 2008, 123, 951-957. [CrossRef] [PubMed]

38. Wang, C.Y.; Shui, H.A.; Chang, T.C. In vivo evidence of duality effects for lovastatin in a nude mouse cancer model. Int. J. Cancer 2010, 126, 578-582. [CrossRef] [PubMed]

39. Ajith, T.A.; Harikumar, K.B.; Thasna, H.; Sabu, M.C.; Babitha, N.V. Proapoptotic and antitumor activities of the HMG-CoA reductase inhibitor, lovastatin, against Dalton's lymphoma ascites tumor in mice. Clin. Chim. Acta 2006, 366, 322-328. [CrossRef] [PubMed]

40. Williams, A.B.; Li, L.; Nguyen, B.; Brown, P.; Levis, M.; Small, D. Fluvastatin inhibits FLT3 glycosylation in human and murine cells and prolongs survival of mice with FLT3/ITD leukemia. Blood 2012, 120, 3069-3079. [CrossRef] [PubMed]

41. Vintonenko, N.; Jais, J.P.; Kassis, N.; Abdelkarim, M.; Perret, G.Y.; Lecouvey, M.; Crepin, M.; Di Benedetto, M. Transcriptome analysis and in vivo activity of fluvastatin versus zoledronic acid in a murine breast cancer metastasis model. Mol. Pharmacol. 2012, 82, 521-528. [CrossRef] [PubMed]

42. Ajith, T.A.; Anu, V.; Riji, T. Antitumor and apoptosis promoting properties of atorvastatin, an inhibitor of HMG-CoA reductase, against Dalton's Lymphoma Ascites tumor in mice. J. Exp. Ther. Oncol. 2008, 7, 291-298. [PubMed]

43. Wang, H.; Cui, X.X.; Goodin, S.; Ding, N.; Van Doren, J.; Du, Z1.; Huang, M.T.; Liu, Y.; Cheng, X.; Dipaola, R.S.; et al. Inhibition of IL-6 expression in LNCaP prostate cancer cells by a combination of atorvastatin and celecoxib. Oncol. Rep. 2014, 31, 835-841. [PubMed]

44. Jeon, C.Y.; Goodman, M.T.; Cook-Wiens, G.; Sundaram, V. Statin use and survival with early stage hepatocellular carcinoma. Cancer Epidemiol. Biomarkers Prev. 2016, 25, 686-692. [CrossRef] [PubMed]

45. Bachy, E.; Estell, J.A.; Van de Neste, E.; Bouabdallah, R.; Bargay, J.; Delmer, A.; Gelas-Dore, B.; Gomes da Silva, M.; Fitoussi, O.; Belada, D.; et al. Statin use is safe and does not impact prognosis in 
patient with de novo follicular lymphoma treated with immunochemotherapy: An exploratory analysis of the PRIMA cohort study. Am. J. Hematol. 2016, 91, 410-415. [CrossRef] [PubMed]

46. Keskiväli, T.; Kujala, P.; Visakorpi, T.; Tammela, T.L.; Murtola, T.J. Statin use and risk of disease recurrence and death after radical prostatectomy. Prostate 2016, 76, 469-478. [CrossRef] [PubMed]

47. Fukamachi, T.; Saito, H.; Kobayashi, H. Effect of simvastatin on immune cells under alkaline and acidic conditions. J. Cancer Sci. Ther. 2015, 7, 48-54. [CrossRef]

48. Carter, A.A.; Gomes, T.; Camacho, X.; Juurlink, D.N.; Shah, B.R.; Mamdani, M.M. Risk of incident diabetes among patients treated with statins: Population based study. BMJ 2013, 346, f2610. [CrossRef] [PubMed]

49. Taylor, F.; Huffman, M.D.; Macedo, A.F.; Moore, T.H.; Burke, M.; Davey Smith, G.; Ward, K.; Ebrahim, S. Statins for the primary prevention of cardiovascular disease. Cochrane Database Syst. Rev. 2013, 1, CD004816.

50. Welty, F.K. Hypobetalipoproteinemia and abetalipoproteinemia. Curr. Opin. Lipidol. 2014, 25, 161-168. [CrossRef] [PubMed]

51. Anderson, M.; Moshnikova, A.; Engelman, D.M.; Reshetnyak, Y.K.; Andreev, O.A. Probe for the measurement of cell surface pH in vivo and ex vivo. Proc. Natl. Acad. Sci. USA 2016, 113, 8177-8181. [CrossRef] [PubMed]

52. Moon, B.F.; Jones, K.M.; Chen, L.Q.; Liu, P.; Randtke, E.A.; Howison, C.M.; Pagel, M.D. A comparison of iopromide and iopamidol, two acidoCEST MRI contrast media that measure tumor extracellular $\mathrm{pH}$. Contrast Media Mol. Imaging 2015, 10, 446-455. [CrossRef] [PubMed]

53. Fukamachi, T.; Ikeda, S.; Saito, H.; Tagawa, M.; Kobayashi, H. Expression of acidosis-dependent genes in human cancer nests. Mol. Clin. Oncol. 2014, 2, 1160-1166. [CrossRef] [PubMed]

54. Chen, B.; Liu, J.; Ho, T.T.; Ding, X.; Mo, Y.Y. ERK-mediated NF-кB activation through ASIC1 in response to acidosis. Oncogenesis 2016, 5, e279. [CrossRef] [PubMed]

(C) 2017 by the author. Licensee MDPI, Basel, Switzerland. This article is an open access article distributed under the terms and conditions of the Creative Commons Attribution (CC BY) license (http:/ / creativecommons.org/licenses/by/4.0/). 